\title{
I Shall Not Submit
}

A child sojourns in solitude.

His eyes at the zenith,

Of not misery, not fear.

Raking and combing the bleak sky,

With a glaring countenance.

A countenance that speaks to the heavens themselves:

"I shall not submit."

A shadow upon the edge of the fog,

A memory - a forbidden childhood.

Never resting, never sleeping,

A ghostly wanderer,

With a penchant for Cain.

With those who housed him saying:

"He shall not submit."

Beneath the love that alters not,

A love not of softness, but of harsh spite.

A caress not of kindness,

But of hatred unending,

With a hunger to swallow the world,

A regime that despises those not of its children

"Who shall not submit."

So why does this child sojourn in solitude?

Why does this ghost wander resolutely?

Why does this love despise those not of its children?

Because of the voice.

The voice inside that shouts,

Not a shout, but a whisper:

"We shall not submit."

For my grandfather:

A man of courage like I have never known.

Alexander Nico-Katz - Age 14 
